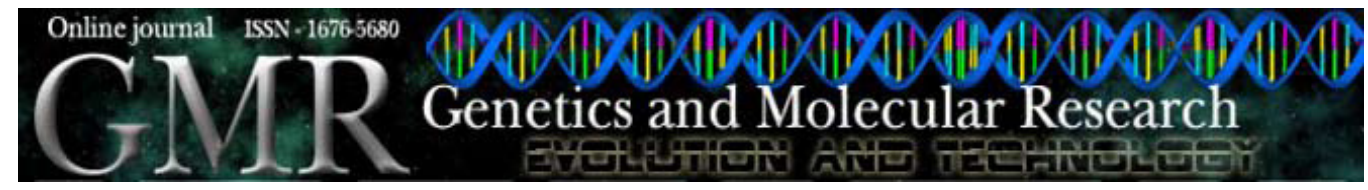

\title{
Detection of polymorphisms of the mtDNA control region of Caretta caretta (Testudines: Cheloniidae) by PCR-SSCP
}

\author{
E.C. Reis ${ }^{1}$, R.M. Albano ${ }^{2}$, A.C.V. Bondioli ${ }^{3}$, L.S. Soares ${ }^{4}$ and \\ G. Lôbo-Hajdu ${ }^{1}$ \\ ${ }^{1}$ Departamento de Genética, Universidade do Estado do Rio de Janeiro, \\ Rio de Janeiro, RJ, Brasil \\ ${ }^{2}$ Departamento de Bioquímica, Universidade do Estado do Rio de Janeiro, \\ Rio de Janeiro, RJ, Brasil \\ ${ }^{3}$ Museu de Zoologia, Universidade de São Paulo, São Paulo, SP, Brasil \\ ${ }^{4}$ Fundação Centro Brasileiro de Proteção e \\ Pesquisa das Tartarugas Marinhas, \\ Projeto TAMAR-ICMBIO (Projeto Tartaruga Marinha - \\ Instituto Chico Mendes de Conservação da Biodiversidade, \\ Salvador, BA, Brasil \\ Corresponding author: E.C. Reis \\ E-mail: est.cardinot@gmail.com
}

Genet. Mol. Res. 8 (1): 215-222 (2009)

Received December 5, 2008

Accepted December 15, 2008

Published February 25, 2009

\begin{abstract}
Marine turtles are increasingly being threatened worldwide by anthropogenic activities. Better understanding of their life cycle, behavior and population structure is imperative for the design of adequate conservation strategies. The mtDNA control region is a fast-evolving matrilineal marker that has been employed in the study of marine turtle populations. We developed and tested a simple molecular tracing system for Caretta caretta mtDNA haplotypes by polymerase chain reaction-single strand conformation polymorphism (PCR-SSCP). Using this technique, we were able to distinguish the SSCP patterns of 18 individuals of
\end{abstract}


the haplotypes CC-A4, CC-A24 and CCxLO, which are commonly found in turtles sampled on the Brazilian coast. When we analyzed 15 turtles with previously unknown sequences, we detected two other haplotypes, in addition to the other four. Based on DNA sequencing, they were identified as the CC-A17 and CC-A1 haplotypes. Further analyses were made with the sea turtles, Chelonia mydas $(\mathrm{N}=8)$, Lepidochelys olivacea $(\mathrm{N}=3)$ and Eretmochelys imbricata $(\mathrm{N}=1)$, demonstrating that the PCR-SSCP technique is able to distinguish intra- and interspecific variation in the family Cheloniidae. We found that this technique can be useful for identifying sea turtle mtDNA haplotypes, reducing the need for sequencing.

Key words: Single strand conformation polymorphism; Sea turtles; Polymorphism; Mitochondrial DNA

\section{INTRODUCTION}

Environmental pressure caused by human interference in the form of commercial fisheries, bycatch and habitat destruction has forced conservation agencies to declare that most marine turtle populations are currently threatened (Lutcavage et al., 1997; IUCN, 2007). Studies have been conducted worldwide to unravel their life cycle, reproduction, migratory behavior, and population structure. The recent tools used for this purpose have been telemetry (Revelles et al., 2007; Lohmann et al., 2008) and genetics (Bowen et al., 2004, 2005; Bowen and Karl, 2007; Velez-Zuazo et al., 2008). Considering that sea turtle's life history makes it notoriously difficult to gather information using traditional mark-recapture strategies, these tools have been pivotal.

Nucleotide polymorphisms accumulated in each population are indicative of genetic variability and of the evolutionary history of individuals. One of the most useful molecules for genetic analysis is the mitochondrial DNA (mtDNA) control region, as it shows a high rate of nucleotide substitutions and rare recombination events and as it is maternally inherited (Allard et al., 1994; Lahanas et al., 1994; Norman et al., 1994; Bowen and Karl, 1996). The relatively rapid rate of mutation allows fine-scale resolution of populations, and for this reason, this genetic marker is used worldwide for population studies of several turtle species (FitzSimmons et al., 1999; Bowen and Karl, 1996, 2007).

In Brazil, five sea turtle species can be found: Caretta caretta, Chelonia mydas, Eretmochelys imbricata, Lepidochelys olivacea, and Dermochelys coriacea (Marcovaldi and dei Marcovaldi, 1999). C. caretta (Linnaeus, 1758) is the most abundant species in relation to the number of nesting areas along the Brazilian coast. The rookeries in Brazil comprise the beaches of Rio de Janeiro to Sergipe States, where they are concentrated in Bahia State (Figure 1). Under IUCN criteria, the loggerhead turtle $(C$. caretta), the olive ridley (L. olivacea), and the green turtle (C. mydas) are currently considered endangered, while the leatherback turtle $(D$. coriacea $)$ and the hawksbill turtle (E. imbricata) are classified as critically endangered (IUCN, 2007). 


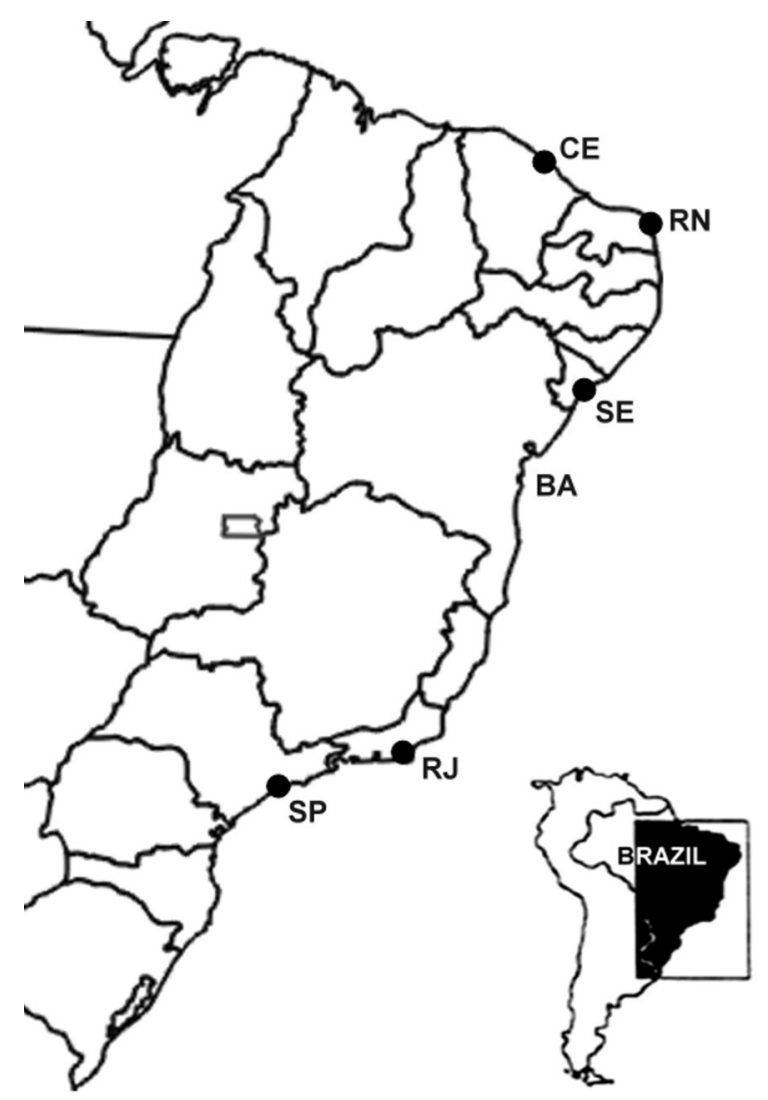

Figure 1. Distribution of Caretta caretta rookeries along the Brazilian coast and collection sites of Chelonia mydas, Caretta caretta, Lepidochelys olivacea, and Eretmochelys imbricata samples. CE $=$ Ceará, $\mathrm{RN}=$ Rio Grande do Norte, $\mathrm{SE}=$ Sergipe, $\mathrm{BA}=$ Bahia, $\mathrm{RJ}=$ Rio de Janeiro, and SP $=$ São Paulo States.

The aim of present study was to establish a tracing system for sea turtle mtDNA haplotypes using a quick method such as polymerase chain reaction amplification followed by single strand conformation polymorphism analysis (PCR-SSCP). This technique is simple to set up in the laboratory and is highly effective for mutation detection (Orti et al., 1997; Sunnucks et al., 2000; Huby-Chilton et al., 2006).

\section{MATERIAL AND METHODS}

Tissue samples of $C$. caretta females were collected using 6-mm disposable biopsy punches in rookeries from the north coast of Rio de Janeiro, Sergipe and Rio Grande do Norte States (Figure 1) during nesting seasons (from November to March). One sample of incidental capture from Ceará and one from Sergipe States were also used. Supplementary analyses were carried out using eight $C$. mydas samples of incidental capture from islands on the south coast of São Paulo State, three females of L. olivacea from Sergipe and one 
E. imbricata sample of a stranded carcass from São Paulo State (Figure 1). The material was collected by trained biologists from Projeto TAMAR-ICMBio (The Brazilian Sea Turtle Conservation Program) and IPeC (Cananéia Research Institute). The present study followed all ethical guidelines and legal requirements of Brazil concerning the sampling of an endangerment species.

Genomic DNA extraction was performed according to a modified protocol from Damato and Corach (1996). The mtDNA control region was amplified using primers LCM15382 (5' - GCT TAA CCC TAA AGC ATT GG - 3'; Abreu-Grobois et al., 2006) and H599 (5' - TGC ACG GCC AAT CAT TTT GAA CGT AG - 3'; Laurent et al., 1998), according to the conditions described by Shanker et al. (2004). The amplified fragment was purified using GFX ${ }^{\mathrm{TM}}$ PCR DNA and gel band purification kit (GE Healthcare). Direct DNA sequencing was performed with the ET Dye terminator cycle sequence kit (GE Healthcare) and analyzed in a MegaBace 1000 automated sequencer (GE Healthcare).

For SSCP analysis (Orita et al., 1989), the purified amplicon was mixed with an equal volume of denaturing loading buffer $(10 \mathrm{mM} \mathrm{NaOH}, 95 \%$ formamide, $0.25 \%$ bromophenol blue, $0.25 \%$ xylene cyanol), incubated at $96^{\circ} \mathrm{C}$ for $5 \mathrm{~min}$, and immediately placed on ice. This mixture was loaded on a non-denaturing 8\% acrylamide gel (99:1 acrylamide:bis-acrylamide) (Sambrook et al., 1989), and run for $40 \mathrm{~h}$ at $15 \mathrm{~V} / \mathrm{cm}$ in a cold chamber $\left(4^{\circ} \mathrm{C}\right)$. Afterwards, the gels were stained with silver nitrate according to Bassam et al. (1991) and dried, and the image was digitized. The assigned SSCP haplotypes were checked by later direct automated DNA sequencing to confirm haplotype determination.

For each PCR amplicon, a consensus sequence was produced by the BioEdit sequence alignment editor, version 7.0.1 (Hall, 1999). Mitochondrial haplotypes were classified by comparison with known $C$. caretta and C. mydas mtDNA control region haplotypes of Atlantic and Mediterranean seas deposited at the Archie Carr Center for Sea Turtle Research database (ACCSTR, 2008).

\section{RESULTS}

To test the potential of the SSCP technique to trace C. caretta mtDNA control region haplotypes, we used samples obtained from 18 individuals representing three different haplotypes previously known for the Rio de Janeiro and Sergipe States. SSCP analysis perfectly discriminated the three haplotypes. Seven turtles were of haplotype CC-A4, four of CC-A24 and seven of CCxLO (Figure 2A). These latter individuals were considered hybrids, as they showed external morphology that resembled that of $C$. caretta but had mtDNA of L. olivacea (Eschscholtz, 1829).

In order to determine if SSCP analysis could be used to discriminate haplotypes in a blind test, we analyzed 15 samples of unknown haplotypes. As shown in Figure 2B, samples $81,82,85,95,97,98,99,116$, and 118 showed the same band pattern as sample 70, which was used as a standard for the CC-A4 haplotype. Samples 96, 117, 119, and 120 were indistinguishable from sample 69, the standard for the CCxLO haplotype. Sample 78 was used as a standard for the CC-A24 haplotype. However, two new patterns could be observed on this gel for samples 83 and 84 . After DNA sequencing, they were identified as being the CC-A17 (sample 83) and CC-A1 (sample 84) haplotypes, which, up to now, had not been reported for the Brazilian coast. The identity of all of the designated haplotypes was confirmed by DNA 
sequencing, and in all cases, there was complete agreement. These sequences were deposited at GenBank under the accession Nos. EU365967-EU365972.
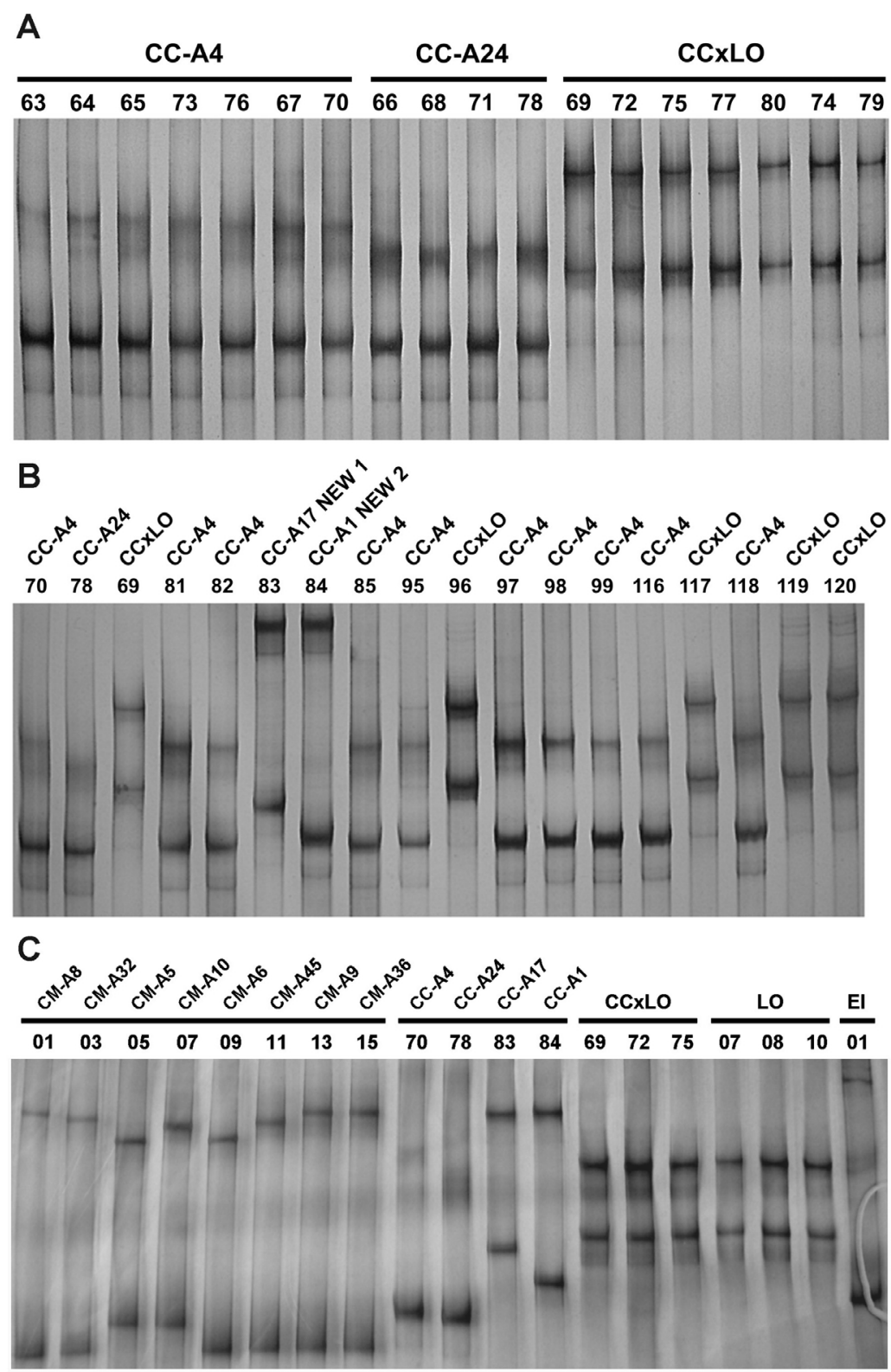

Figure 2. Single strand conformation polymorphism analysis of mtDNA control region haplotypes of Chelonia mydas, Caretta caretta, Lepidochelys olivacea, and Eretmochelys imbricata, on a non-denaturing $8 \%$ acrylamide gel. Samples are numbered according to the UERJ DNA database entry $(\mathrm{CM}=$ Chelonia mydas, $\mathrm{CC}=$ Caretta caretta, $\mathrm{LO}$ $=$ Lepidochelys olivacea, $\mathrm{EI}=$ Eretmochelys imbricate, and $\mathrm{CCxLO}=$ hybrids between $C$. caretta and L. olivacea). 
In Figure 2A and $\mathrm{B}$, it is noted that the SSCP CC-A4 haplotype pattern is most similar to the CC-A24 pattern. When the nucleotide sequences were examined, it could be seen that the difference between the CC-A4 and CC-A24 haplotypes involves only one polymorphic site (a transition). On the other hand, the CCxLO hybrid haplotype differs from the CC-A4 haplotype by 37 nucleotides ( 24 transitions, 6 transversions and 7 indels), and from the CC-A24 by 38 polymorphic sites ( 25 transitions, 6 transversions and 7 indels). Moreover, SSCP patterns obtained for sample 83 (CC-A17) and 84 (CCA1) resembled each other and were quite distinct from the others (CC-A4, CC-A24, and $\mathrm{CCxLO}$ ). After DNA sequence analysis, we observed that the difference between the CCA17 and CC-A1 haplotypes is only in one polymorphic site (one transition).

To ensure that the SSCP technique could be applied to distinguish mtDNA haplotypes from other sea turtles, eight C. mydas, three L. olivacea and one E. imbricata samples of known sequences were analyzed (Figure 2C). Samples revealed a higher intraspecific variability in C. mydas, with eight different haplotypes, named CM-A5, A6, A8, A9, A10, A32, A36, and A45 according to the ACCSTR database. In contrast, L. olivacea showed a unique pattern, matching the one found for $\mathrm{CCxLO}$ samples. The E. imbricata pattern is distinct from the ones of the other three species. The difference in nucleotide sequence between pairs of $C$. mydas haplotypes varies from one to three nucleotides, including seven transitions and one transversion.

\section{DISCUSSION}

The sensitivity of the SSCP technique was demonstrated by the total congruence $(100 \%)$ between banding patterns and nucleotide sequence haplotypes assigned for the 45 samples of the four species tested. The SSCP patterns could clearly discriminate haplotypes that differed by only one nucleotide, as observed in other studies (Orti et al., 1997; Sunnucks et al., 2000).

With the application of the SSCP technique, we were able to identify two new C. caretta haplotype patterns, which turned out to be new registers of known haplotypes (CC-A1 and CC-A17) for the Brazilian coast. These haplotypes have been previously reported by Bolten et al. (1998) for pelagic juvenile populations from the Azores (CC-A1) and Madeira (CC-A1 and CC-A17). In fact, CC-A 1 is one of the most frequently detected haplotypes in western north Atlantic nesting populations (Bowen et al., 2004).

Among the C. mydas haplotypes found in the present study, CM-36 was previously observed for the East-Atlantic coast of Africa, at São Tomé Island rookery (Formia et al., 2006), and reported for the first time for Brazil (Bondioli ACV, unpublished results). CM-A8, CM-A9, CM-A10, and CM-A32 haplotypes were already reported for foraging grounds (Ubatuba and Almofala) and rookeries (Trindade Island and Rocas Atoll) in Brazil, while CM-5, CM-6, and CM-45 were only observed at the Brazilian foraging grounds (Naro-Maciel et al., 2007). The E. imbricata haplotype found was already reported for Bahia, Brazil (Lara-Ruiz et al., 2006).

These results show that the PCR-SSCP method applied to the analysis of sea turtle mtDNA control region is efficient in distinguishing species in the family Cheloniidae and its haplotypes. This simple and fast technique could also be employed to reduce sequencing efforts. 


\section{ACKNOWLEDGMENTS}

Special thanks go to CENPES/PETROBRAS (Centro de Pesquisas da PETROBRAS), which supported the "Mamíferos e Quelônios Marinhos" project, to which this work is connected. The Projeto TAMAR-ICMBio and Instituto de Pesquisas Cananéia (IPeC) staff collected the samples and provided the necessary field assistance. Research supported by CEBIOIBRAG (Centro de Biologia do Instituto de Biologia Roberto Alcantara Gomes), CAPES, PROCIÊNCIA-SR2-UERJ, PPGB-UERJ, FAPERJ, and CNPq/MCT.

\section{REFERENCES}

Abreu-Grobois AF, Horrocks J, Formia A, Dutton P, et al. (2006). New mtDNA Primers which Work for a Variety of Marine Turtle Species may Increase the Resolution of Mixed Stock Analysis. In: Proceedings of the 26th Annual Symposium on Sea Turtle Biology and Conservation (Frick M, Panagopoulous A, Rees AF and Williams K, eds.). International Sea Turtle Society, Athens, 179. Available at [http://www.nmfs.noaa.gov/pr/pdfs/species/turtlesymposium2006_abstracts.pdf].

ACCSTR (2008). Archie Carr Center for Sea Turtle Research, Marine Turtle DNA Sequence Patterns. University of Florida, Gainesville. Available at [http://accstr.ufl.edu/ccmtdna.html]. Accessed December 2008.

Allard MW, Miyamoto MM, Bjorndal KA, Bolton AB, et al. (1994). Support for natal homing in green turtles from mitochondrial DNA sequences. Copeia 1: 34-41.

Bassam BJ, Caetano-Anolles G and Gresshoff PM (1991). Fast and sensitive silver staining of DNA in polyacrylamide gels. Anal. Biochem. 196: 80-83.

Bolten AB, Bjorndal KA, Martins HR, Dellinger T, et al. (1998). Transatlantic developmental migrations of loggerhead sea turtles demonstrated by mtDNA sequence analysis. Ecol. Appl. 8: 1-7.

Bowen BW and Karl SA (1996). Population Genetics, Phylogeography and Molecular Evolution. In: The Biology of Sea Turtles. Vol. 1 (Lutz PL and Musick JA, eds.). CRC Press, Boca Raton, 29-50.

Bowen BW and Karl SA (2007). Population genetics and phylogeography of sea turtles. Mol. Ecol. 16: 4886-4907.

Bowen BW, Bass AL, Chow SM, Bostrom M, et al. (2004). Natal homing in juvenile loggerhead turtles (Caretta caretta). Mol. Ecol. 13: 3797-3808.

Bowen BW, Bass AL, Soares L and Toonen RJ (2005). Conservation implications of complex population structure: lessons from the loggerhead turtle (Caretta caretta). Mol. Ecol. 14: 2389-2402.

Damato ME and Corach D (1996). Genetic diversity of populations of the freshwater shrimp Macrobrachium borelli (Cardidea, Palaemonidae) evaluated by RAPD analysis. J. Crust. Biol. 16: 650-655.

FitzSimmons NN, Moritz C and Bowen BW (1999). Population Identification. In: Research and Management Techniques for the Conservation of Sea Turtles. No. 4 (Eckert KL, Bjorndal KA, Abreu-Grobois FA and Donnelly M, eds.). IUCN/SSC Marine Turtle Specialist Group Publication, Washington DC, 72-82.

Formia A, Godley BJ, Dontaine JF and Bruford MW (2006). Mitochondrial DNA diversity and phylogeography of endangered green turtle (Chelonia mydas) populations in Africa. Conserv. Genet. 7: 353-369.

Hall AT (1999). BioEdit: a user-friendly biological sequence alignment editor and analysis program for Windows 95/98/ NT. Nucleic Acids Symp. Ser. 41: 95-98.

Huby-Chilton F, Chilton NB, Lankester MW and Gajadhar AA (2006). Single-strand conformation polymorphism (SSCP) analysis as a new diagnostic tool to distinguish dorsal-spined larvae of the Elaphostrongylinae (Nematoda: Protostrongylidae) from cervids. Vet. Parasitol. 135: 153-162.

IUCN (International Union for the Conservation of Nature) (2007). International Union for the Conservation of Nature and Natural Resources, Red List of Threatened Species. Available at [http://www.iucnredlist.org/]. Accessed December 2008.

Lahanas PN, Miyamoto MM, Bjorndal KA and Bolten AB (1994). Molecular evolution and population genetics of Greater Caribbean green turtles (Chelonia mydas) as inferred from mitochondrial DNA control region sequences. Genetica 94: 57-66.

Lara-Ruiz P, Lopez GG, Santos FR and Soares LS (2006). Extensive hybridization in hawksbill turtles (Eretmochelys imbricata) nesting in Brazil revealed by mtDNA analyses. Conserv. Genet. 7: 773-781.

Laurent L, Casale P, Bradai MN, Godley BJ, et al. (1998). Molecular resolution of marine turtle stock composition in fishery bycatch: a case study in the Mediterranean. Mol. Ecol. 7: 1529-1542.

Lohmann KJ, Luschi P and Hays GC (2008). Goal navigation and island-finding in sea turtles. J. Exp. Mar. Biol. Ecol. 356: 83-95. 
Lutcavage ME, Plotkin P, Witherington B and Lutz PL (1997). Human Impacts on Sea Turtle Survival. In: The Biology of Sea Turtles. Vol. 1 (Lutz PL and Musick JA, eds.). CRC Press, Boca Raton, 387-409.

Marcovaldi MA and dei Marcovaldi GG (1999). Marine turtles of Brazil: the history and structure of Projeto TAMARIBAMA. Biol. Conserv. 91: 35-41.

Naro-Maciel E, Becker JH, Lima EH, Marcovaldi MA, et al. (2007). Testing dispersal hypotheses in foraging green sea turtles (Chelonia mydas) of Brazil. J. Hered. 98: 29-39.

Norman JA, Moritz C and Limpus CJ (1994). Mitochondrial DNA control region polymorphisms: genetic markers for ecological studies of marine turtles. Mol. Ecol. 3: 363-373.

Orita M, Suzuki Y, Sekiya T and Hayashi K (1989). Rapid and sensitive detection of point mutations and DNA polymorphisms using the polymerase chain reaction. Genomics 5: 874-879.

Orti G, Hare MP and Avise JC (1997). Detection and isolation of nuclear haplotypes by PCR-SSCP. Mol. Ecol. 6: 575-580.

Revelles M, Cardona L, Aguilar A, San Félix M, et al. (2007). Habitat use by immature loggerhead sea turtles in the Algerian Basin (western Mediterranean): swimming behaviour, seasonality and dispersal pattern. Mar. Biol. 151: 1501-1515.

Sambrook J, Fritsch EF and Maniatis T (1989). Molecular Cloning: A Laboratory Manual. Cold Spring Harbor Laboratory Press, Cold Spring Harbor.

Shanker K, Ramadevi J, Choudhury BC, Singh L, et al. (2004). Phylogeography of olive ridley turtles (Lepidochelys olivacea) on the east coast of India: implications for conservation theory. Mol. Ecol. 13: 1899-1909.

Sunnucks P, Wilson AC, Beheregaray LB, Zenger K, et al. (2000). SSCP is not so difficult: the application and utility of singlestranded conformation polymorphism in evolutionary biology and molecular ecology. Mol. Ecol. 9: 1699-1710.

Velez-Zuazo X, Ramos WD, van Dam RP, Diez CE, et al. (2008). Dispersal, recruitment and migratory behaviour in a hawksbill sea turtle aggregation. Mol. Ecol. 17: 839-853. 